\title{
Effects of Different Nutrient Solutions on the Acclimatisation of in vitro Caladium Plantlets using a Simplified Hydroponic System
}

\author{
(Kesan Larutan Nutrien yang Berbeza pada Pengikliman in vitro Anak Benih Caladium
} menggunakan Sistem Hidroponik Dipermudah)

\author{
YUAN-SHAN ZHANG, Si-JiA GU, Jin-Jin CHEN \& XIAO-DONG CAI*
}

\begin{abstract}
An efficient acclimatisation protocol is critical to improve the survival rate and promote growth of in vitro plantlets. Herein, tissue-cultured plantlets of 'Red Flash' caladium (Caladium $\times$ hortulanum Birdsey) were treated with deionised water and three nutrient solutions including Japanese garden formula (JG), South China Agriculture University formula $B$ for leafy vegetables (SCAU-B) and Hoagland solution in a simplified hydroponic system under indoor environmental conditions. The results showed that all the plantlets survived after 30 days of hydroponic culture, and the three nutrient solutions showed significant positive effects on the plant growth and the content of chlorophyll a, chlorophyll b, total chlorophyll, carotenoid, soluble sugar and soluble protein compared to the deionised water treatment. No significant difference was recorded for the other growth parameters except the average leaf number per plantlet among the nutrient solution treatments. For the analysed physiological parameters, the plantlets treated by SCAU-B contained significantly higher content than those of the Hoagland treatment except the protein content. No significant difference was found between the JG and the SCAU-B treatment except the carotenoid content, and between the JG and the Hoagland treatment except the protein content. The plantlets acclimatised in the nutrient solutions also had a good performance when transferred to plastic pots. These results implied that water alone was not capable of maintaining healthy growth of in vitro caladium plantlets, and hydroponics approach using the three nutrient solutions could be a feasible method for acclimatisation of the plantlets.
\end{abstract}

Keywords: Caladium $\times$ hortulanum Birdsey; morphological characteristics; nutrient solution; physiological changes

\section{ABSTRAK}

Protokol pengikliman yang cekap adalah penting untuk meningkatkan kadar kemandirian dan menggalakkan pertumbuhan anak pokok secara in vitro. Dalam kajian ini, anak pokok kultur tisu bagi 'Red Flash' kaladium (Caladium $\times$ hortulanum Birdsey) telah dirawat dengan air ternyahion dan tiga larutan nutrien termasuk formula taman Jepun (JG), formula $B$ South China Agriculture untuk sayuran berdaun (SCAU-B) dan Larutan Hoagland dalam sistem hidroponik mudah dalam keadaan persekitaran tertutup. Hasil kajian menunjukkan bahawa semua anak pokok bermandiri selepas 30 hari dalam kultur hidroponik, dan ketiga-tiga larutan nutrien menunjukkan kesan positif yang signifikan terhadap pertumbuhan tumbuhan dan kandungan klorofil a, klorofil b, jumlah klorofil, karotenoid, gula larut dan protein larut berbanding dengan rawatan air ternyahion. Tiada perbezaan yang signifikan direkodkan untuk parameter pertumbuhan lain kecuali bilangan purata daun bagi setiap anak pokok antara rawatan larutan nutrien. Untuk parameter fisiologi yang dianalisis, anak pokok yang dirawat oleh SCAU-B mengandungi kandungan yang lebih tinggi secara signifikan berbanding rawatan Hoagland kecuali kandungan protein. Tiada perbezaan yang signifikan antara rawatan JG dan SCAU-B kecuali kandungan karotenoid, serta antara rawatan JG dan Hoagland kecuali kandungan protein. Anak pokok yang diiklimkan dalam larutan nutrien juga mempunyai prestasi yang baik apabila dipindahkan ke dalam bekas plastik. Hasil kajian ini menunjukkan bahawa air sahaja tidak dapat mengekalkan pertumbuhan sihat anak pokok kaladium secara in vitro, dan pendekatan hidroponik menggunakan ketiga-tiga larutan nutrien itu boleh menjadi kaedah yang sesuai untuk pengikliman tanaman.

Kata kunci: Caladium $\times$ hortulanum Birdsey; ciri morfologi; larutan nutrien; perubahan fisiologi

\section{INTRODUCTION}

Caladium (Caladium $\times$ hortulanum Birdsey) is an important ornamental plant valued for its long-lasting colorful foliage, and is commonly grown in containers and in the landscape (Deng 2018, 2012). A great deal of reports indicated that caladium could be propagated by in vitro culturing of leaf segments, meristematic tissues or petiole segments (Ahmed et al. 2004; Cai \& Deng 2016; Thongpukdee et al. 2010), and morphological variants were frequently observed among these regenerated plants (Cai et al. 2015; Cao et al. 2016). Recent studies found that chromosome gain or loss was a common type of cytological variation in caladium (Cai et al. 2015; Cao et al. 2016). Although the variations caused by in vitro culture may limit 
the application of tissue culture technology in agriculture, valuable variations could be potential source materials for genetic improvement and breeding of caladium.

In vitro plantlets are commonly incubated in culturing vessels in an enclosed environment characterised by limited gas exchanges, constant temperature, high relative humidity and sterile condition, resulting in limited leaf surface wax layers, low stomata number, poor photosynthesis and weak root absorption of the plantlets (Pospóšilová et al. 1999). Compared to greenhouse plants, the leaves of in vitro plantlets had bigger stomata with larger pore area, higher stomata densities and higher epidermal densities (Asayesh et al. 2017). Due to these abnormalities, transition to ex vitro conditions frequently leads to a relatively high percentage of plant death due to serious environmental stresses (Kozai 1991; Pospóšilová et al. 1999). Therefore, it is an important step to improve the survival rate and promote healthy growth of the regenerated plantlets during the acclimatisation process for an efficient in vitro propagation protocol. In caladium, in vitro plantlets were commonly transplanted to containers or pots containing different substrate mixtures under controlled conditions such as an artificial climate box, where regular water and fertilisation for several weeks were needed during the acclimatisation process (Cai et al. 2015; Cao et al. 2016). The plantlets were gradually acclimated to ambient atmospheric conditions, which was a difficult stage and a labor intensive process.

Hydroponics is a soilless culture system for growing plants with the root systems emerging in the water solution containing appropriate mineral nutrients under controlled growth conditions, and it is considered as a highly efficient way and a water-saving method in numerous plants worldwide (Bradley \& Marulanda 2001). Composition, concentration, $\mathrm{pH}$, electric conductivity (EC), temperature and oxygenation of nutrient solution are important factors that may affect plant growth and development (Hosseinzadeh et al. 2017). Recently, advances have been made in investigating suitable hydroponic culture conditions for a variety of ornamental plants (Banijamali et al. 2018; Phantong et al. 2018; Sutthinon et al. 2015) including caladium (Li et al. 2010; Phonpho \& Saetiew 2017; Xu \& Cui 2014;). In addition, several reports suggested that hydroponics could be successfully applied in acclimatisation of in vitro produced plantlets, such as Solanum tuberosum L. (Nhut et al. 2006), Stemona curtisii Hook. f. (Palee et al. 2012) and Grammatophyllum speciosum Blume (Sutthinon et al. 2015). In these studies, hydroponics had been proved to be a feasible alternative to acclimatise in vitro plantlets in a clean, convenient and water-saving way. However, there has been little information about an efficient method for acclimatisation of in vitro caladium plantlets using a hydroponic system. Nutrient solution formula is an important factor affecting the growth process and final yield and quality of crops (Trejo-Téllez \& Gómez-Merino 2012). Quite a few nutrient solution formulations have been published to define the balanced concentrations of essential microelements and macroelements, such as Japanese garden formula (JG) included by Liu (2001), South China Agriculture University formula B for leafy vegetables (SCAU-B) described by Liu (2001) and Hoagland solution (Hoagland \& Arnon 1950). The nutrient solution can be static or flow continuously to maintain a constant nutrient level and water status in the root zone. Static hydroponics is a type of hydroponic solution culture technique in which plants are grown in static reservoirs of nutrient solution, which is regarded as the oldest soilless and easiest culture technique (Öztekin et al. 2018). It is very popular for home gardening due to its simplicity and low cost. In this study, in vitro plantlets of caladium were grown in simplified hydroponic plant boxes filled with deionised water without any fertiliser, JG, SCAU-B and Hoagland solution (as control), respectively, and the morphological and physiological characteristics of these plantlets were studied to establish a feasible acclimatisation method in a static hydroponic system.

\section{MATERIALS AND METHODS}

\section{PLANTLET ESTABLISHMENT}

Plantlets were produced in vitro from young leaf segments of 'Red Flash' caladium (Caladium $\times$ hortulanum Birdsey) according to the method described by Cai and Deng (2016). Briefly, after washed with running water for 30 min, the leaves were surface disinfected by soaking in $70 \%(\mathrm{v} / \mathrm{v})$ alcohol for $15 \mathrm{~s}$ and then in $0.5 \%(\mathrm{w} / \mathrm{v})$ sodium dichloroisocyanuric acid for $20 \mathrm{~min}$, and rinsed with sterile water three times. The disinfected leaves were cut into small segments (about $0.5 \times 0.5 \mathrm{~cm}$ ) in a laminar flow cabinet, and then cultured on the callus induction medium, i.e., solidified Murashige and Skoog's medium (MS) supplemented with $1 \mathrm{mg} / \mathrm{L}$ thidiazuron (TDZ) and 1 $\mathrm{mg} / \mathrm{L}$ 1-Naphthyl acetic acid (NAA). After 2 months of culture, the induced calli were transferred to MS basal medium with $1 \mathrm{mg} / \mathrm{L}$ 6-benzyladenine (6-BA) and 0.1 $\mathrm{mg} / \mathrm{L}$ NAA (callus differentiation medium) for production of sufficient plantlets. Well-rooted plantlets were taken out from the culture medium and rinsed carefully under running tap water to remove the medium from the roots, and the plantlets of similar height were prepared for the present experiment.

\section{HYDROPONIC APPARATUS}

A simplified hydroponic plant box (length $\times$ width $\times$ height $=50 \mathrm{~cm} \times 27 \mathrm{~cm} \times 34 \mathrm{~cm}$ ) equipped with two LED lamps (10 W each) and a solution tank of $4 \mathrm{~L}$ in volume (Haier Co., Ltd., Qingdao, China) was prepared for the plantlet growth, and there are 30 planting holes $(3 \mathrm{~cm}$ height and 2.5 $\mathrm{cm}$ diameter) in the plastic cover plate as shown in Figure 2(A). A light intensity of about 3500 Lux was measured in the middle of the box, and it has no temperature control device and liquid flow system. 


\section{HYDROPONICS}

To establish a feasible static hydroponic system for acclimatisation of in vitro plantlets of caladium, deionised water, without any fertiliser, and three universal nutrient solutions including full strength of Japanese Garden formula (JG), South China Agriculture University formula B for leafy vegetables (SCAU-B) and Hoagland solution (as control) were prepared. The $\mathrm{pH}$ value of all the treatments was adjusted to 5.8 each time during application of the culture solutions. Four hydroponic devices were used in this study, and each was filled with one type of these culture solutions, respectively. The plantlets were transplanted individually to the hydroponic plant box by pushing the roots through the planting holes into the hydroponic solutions, and a total of 30 plantlets were grown in each hydroponic apparatus.

The plantlets were maintained in the hydroponic boxes for 30 days. The experiment was conducted during the period from May to early July of 2018 in a Lab at the Yangtze University, Jingzhou, China $\left(30^{\circ} 21^{\prime} 26.2^{\prime \prime} \mathrm{N}\right.$, $\left.112^{\circ} 08^{\prime} 57.2^{\prime \prime} \mathrm{E}\right)$ with an ambient temperature between $18^{\circ} \mathrm{C}$ and $32^{\circ} \mathrm{C}$, and relative humidity varied from $55 \%$ to $85 \%$. The plantlets grew with a $14 \mathrm{~h}$ light/10 h dark photoperiod under natural temperature conditions without a cooling/heating system. The hydroponic solutions were replaced by fresh solutions once every 10 days. At the end of the experiment, five healthy individuals in each treatment were selected at random from the 30 plantlets for variable analysis and assays were repeated three times.

\section{VARIABLE ANALYSIS}

After 30 days of hydroponic culture, different growth parameters including the survival rate, plantlet height, number of leaves and roots, and fresh weight per plantlet were collected directly. Leaf tissue without main veins was used to determine the physiological changes including content of photosynthetic pigments (chlorophyll $a$, chlorophyll $b$, total chlorophyll and carotenoid), soluble sugar and soluble protein. Leaf pigments were extracted by soaking and grinding $0.2 \mathrm{~g}$ leaf tissue with a mortar in an $80 \%$ acetone buffer solution according to $\mathrm{Li}$
(2000), and the absorbance of the extract was measured spectrophotometrically at $663 \mathrm{~nm}, 645 \mathrm{~nm}$ and $470 \mathrm{~nm}$, respectively. The content of photosynthetic pigments was calculated using the equations provided by Lichtenthaler (1987). Total soluble sugar content was determined by using the anthrone colorimetry method at $630 \mathrm{~nm}$ according to $\mathrm{Li}$ (2000). Soluble protein content was measured by Coomassie Brilliant Blue G-250 method using bovine serum albumin (BSA) as standard (Bradford 1976).

\section{STATISTICAL ANALYSIS}

Data of different parameters were analyzed statistically by using one-way ANOVA in SPSS statistical software (version 23 for Windows), and significant differences between the means were evaluated using Duncan's multiple range test at $p<0.05$. The data were expressed as the mean value \pm standard deviation.

\section{RESULTS}

\section{CALLUS INDUCTION AND PLANTLET ESTABLISHMENT}

Small amount of callus was observed around the cut surfaces of the explants about 1 month of culture on the callus induction medium, MS basal medium supplemented with $1 \mathrm{mg} / \mathrm{L} \mathrm{TDZ}$ and $1 \mathrm{mg} / \mathrm{L} \mathrm{NAA}$, and the callus was compact with a light yellow color (Figure 1(A)). These calli proliferated slowly and several shoots and/or roots occurred after another month of incubation on the callus induction medium (Figure 1(B)). A large number of vigorously growing plantlets with healthy root system were regenerated from the callus after 3 months of culture on the callus differentiation medium, MS basal medium supplemented with $1 \mathrm{mg} / \mathrm{L} 6-\mathrm{BA}$ and $0.1 \mathrm{mg} / \mathrm{L} \mathrm{NAA}$ (Figure 1(C)). Thus, sufficient plantlets were established for the subsequent study.

\section{PLANTLET GROWTH IN HYDROPONICS}

Plantlets treated by the three nutrient solutions grew more vigorously than those cultured in the deionised water, and

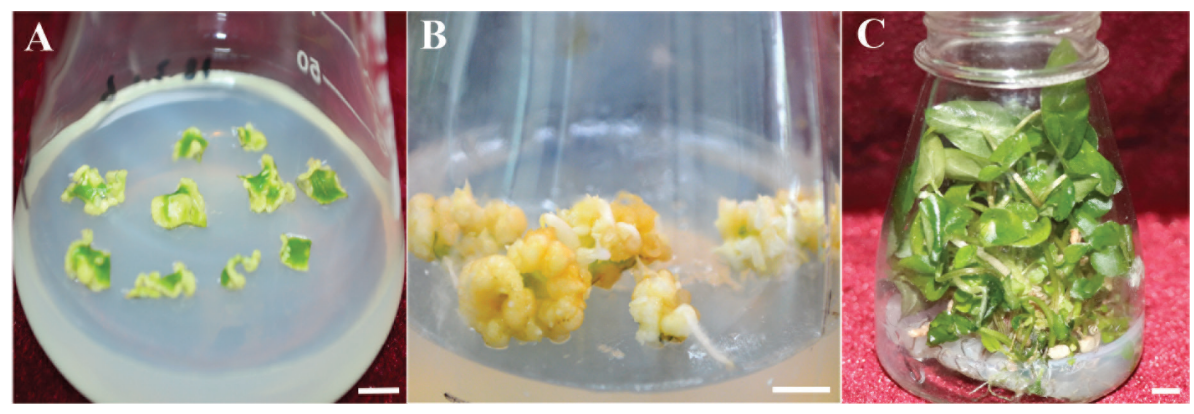

FIGURE 1. Plantlets regenerated from leaf segments of 'Red Flash' caladium (Caladium $\times$ hortulanum Birdsey). A. Callus initiation after about one month of culture on MS basal medium supplemented with $1 \mathrm{mg} / \mathrm{L}$ TDZ and $1 \mathrm{mg} / \mathrm{L}$ NAA (callus induction medium); B. Regenerated calli with shoots and/or roots after two months of culture on the callus induction medium; C. Plantlets regenerated from the calli after three months of culture on MS basal medium supplemented with 1 $\mathrm{mg} / \mathrm{L} 6-\mathrm{BA}$ and $0.1 \mathrm{mg} / \mathrm{L}$ NAA (callus differentiation medium). Scale bars $=1 \mathrm{~cm}$ 
each developed several heart-shaped leaves with red main veins, white blotches, green margins and a red-purple petiole (Figure 2(A)). Compared to the deionised water treatment, all the plantlets cultured in the nutrient solutions showed a higher height and developed more roots and leaves (Figure 2(B)). Moreover, although the plantlets grown in the deionised water showed a poor growth response, it was found that the caladium plantlets treated by not only the nutrient solutions but also the deionised water, all survived in this study.

SURVIVAL RATE AND MORPHOLOGICAL CHARACTERISTICS OF THE IN VITRO CALADIUM PLANTLETS IN HYDROPONICS

The survival rate of the hydroponic plantlets in the deionised water and the three nutrient solutions all reached $100 \%$ (Table 1), suggesting that hydroponic method was feasible and efficient for acclimatisation of the in vitro plantlets of caladium. Data pertaining to the morphological traits after 30 days of hydroponic culture influenced by the different treatment solutions were presented in Table 1. Effects of the hydroponic solutions on the plantlet height were in the following order: SCAU-B $>$ Hoagland $>\mathrm{JG}>$ deionised water, and the plantlets treated by SCAU-B reached a mean height of $22.06 \mathrm{~cm}$, which was nearly two times higher than that of the deionised water treatment. Statistical analysis suggested that all the three nutrient solution treatments significantly increased the plantlet height compared to the deionised water treatment, while it was not significantly different among the three nutrient solution treatments for this growth parameter (Table 1). The mean leaf number per plantlet reached 5.08 when treated with JG, which was significantly higher than that of the other treatments, and no significant difference was found between the SCAU-B and the Hoagland solution treatments (Table 1). For the root number per plantlet, the results showed that there was no significant difference among the three nutrient solution treatments, while all of them significantly increased the root number compared to the deionised water treatment (Table 1). Plant fresh weight is an important parameter related to the growth activity and the nutrient absorption ability of the root system. The highest plantlet fresh weight was observed in the SCAU-B treatment (5.77 g per plant), which was 2.35 times higher than that of the deionised water treatment, while there was no significant difference among the three nutrient solution treatments (Table 1).

\section{VARIANCE OF PHYSIOLOGICAL PARAMETERS OF THE IN VITRO CALADIUM PLANTLETS IN HYDROPONICS}

Variance of physiological parameters related to plantlet growth and development treated by different hydroponic solutions was shown in Table 2. Results showed that the plantlets grown in SCAU-B yielded the highest content of chlorophyll $a$, chlorophyll $b$, total chlorophyll, carotenoid, soluble sugar and soluble protein after 30
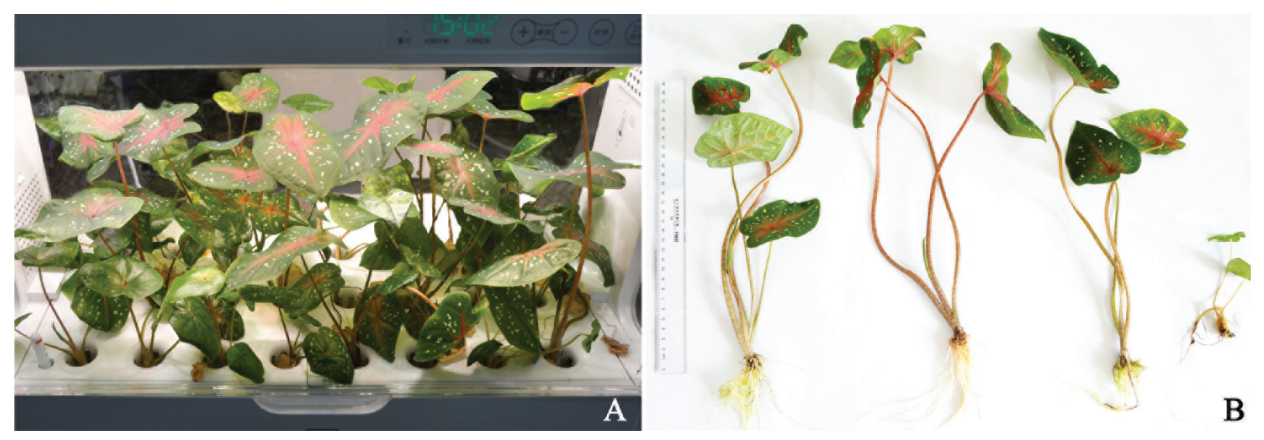

JG: Japan Garden formula; SCAU-B: South China Agriculture University formula B for leafy vegetables

FIGURE 2. Growth of in vitro 'Red Flash' caladium plantlets after 30 days of acclimatization in Hoagland nutrient solution by using a static hydroponics system (A) and plant morphological characteristics of the plantlets after 30 days of

hydroponic culture in JG, SCAU-B, Hoagland solution and deionized water, respectively (from left to right) (B)

TABLE 1. Survival rate and morphological characteristics of the caladium plantlets after 30 days of acclimatization in the different hydroponic solutions by using a static hydroponic system

\begin{tabular}{lccccc}
\hline Treatments & $\begin{array}{c}\text { survival rate } \\
(\%)\end{array}$ & $\begin{array}{c}\text { plantlet height } \\
(\mathrm{cm})\end{array}$ & $\begin{array}{c}\text { Leaf number/plantlet } \\
(\mathrm{no})\end{array}$ & $\begin{array}{c}\text { Root number/plantlet } \\
(\mathrm{no})\end{array}$ & $\begin{array}{c}\text { Fresh weight/ } \\
\text { plantlet } \\
(\mathrm{g})\end{array}$ \\
\hline Deionized water & $100 \mathrm{a}$ & $12.00 \pm 3.41 \mathrm{~b}$ & $3.29 \pm 0.19 \mathrm{c}$ & $12.29 \pm 1.54 \mathrm{~b}$ & $2.46 \pm 0.29 \mathrm{~b}$ \\
JG & $100 \mathrm{a}$ & $17.62 \pm 2.67 \mathrm{a}$ & $5.08 \pm 0.26 \mathrm{a}$ & $16.00 \pm 1.77 \mathrm{a}$ & $4.31 \pm 0.92 \mathrm{a}$ \\
SCAU-B & $100 \mathrm{a}$ & $22.06 \pm 1.91 \mathrm{a}$ & $4.42 \pm 0.36 \mathrm{~b}$ & $15.88 \pm 1.57 \mathrm{a}$ & $5.77 \pm 1.28 \mathrm{a}$ \\
Hoagland & $100 \mathrm{a}$ & $21.61 \pm 2.44 \mathrm{a}$ & $4.33 \pm 0.44 \mathrm{~b}$ & $15.04 \pm 2.70 \mathrm{a}$ & $5.74 \pm 1.44 \mathrm{a}$ \\
\hline
\end{tabular}

Means \pm standard deviation within a column followed by the same letters are not significantly different according to Duncan's range test at $p<0.05$.

JG: Japan Garden formula; SCAU-B: South China Agriculture University formula B for leafy vegetables 
days of hydroponic culture, which increased by $51.4 \%$, $47.9 \%, 50.5 \%, 50.8 \%, 41.1 \%$ and $32.7 \%$, respectively, compared to the deionised water treatment. The plantlets grown in deionised water yielded the lowest content of these physiological parameters, which were all significantly lower than those of other nutrient solution treatments, respectively. The content of photosynthetic pigments including chlorophyll $a$, chlorophyll $b$, total chlorophyll and carotenoid when treated with SCAU-B was all significantly higher than that of the Hoagland solution treatment, and no significant difference was observed between the JG and the SCAU-B treatments for these variances except the carotenoid content. For the soluble sugar content treated by the three nutrient solutions, there was no significant difference between the JG and the Hoagland solution treatments. For the soluble protein content, no significant difference was observed between the SCAU-B and the Hoagland solution treatments, but the two treatments significantly increased the soluble protein content compared to the JG treatment (Table 2).

\section{DISCUSSION}

In caladium, callus, shoots and roots were readily induced from a range of explant types such as leaf segments on a suitable medium (Ahmed et al. 2004; Cai \& Deng 2016; Thongpukdee et al. 2010). In this study, callus formation was also observed when the leaf segments were cultured on the MS basal medium supplemented with $1 \mathrm{mg} / \mathrm{L}$ TDZ and $1 \mathrm{mg} / \mathrm{L}$ NAA. The induced callus was easily differentiated into shoots and/or roots, and could regenerate into plantlets after culturing for several months. Similar results have also been found by Cai and Deng (2016) when developing a procedure for producing friable callus with sustained regeneration potential in caladium.

After well-rooted plantlets established, the most crucial stage for an efficient tissue culture protocol is to improve the survival rate and enhance growth of the regenerated plantlets during the acclimatisation process (Kozai 1991; Pospóšilová et al. 1999; Sutthinon et al. 2015). Different systems including hydroponics have been developed for acclimatisation of in vitro grown plantlets (Nhut et al. 2006; Palee et al. 2012; Sutthinon et al. 2015). In this study, a $100 \%$ survival rate and a superior performance were observed for the in vitro caladium plantlets treated by the three nutrient solutions (Table 1). Physiological analysis showed that the nutrient solution treatments remarkably increased the content of photosynthetic pigments including chlorophyll $a$, chlorophyll $b$, total chlorophyll and carotenoid (Table 2). It is widely known that chlorophyll content is an important indicator of photosynthesis activity and plant status (Bailey et al. 2004). The significant increase in several morphological characteristics of the plantlets grown in the tested nutrient solutions may be related to higher chlorophyll content in the plantlet leaves. Sucrose is one of the primary products of photosynthesis in the leaves of most plants (Kötting et al. 2010), and a relatively high content of chlorophyll is one of preconditions of intensive photosynthesis, which could be the reason why the soluble sugar content increased with increasing chlorophyll content in the plantlet leaves in this study (Table 2). Most soluble proteins are enzymes that participate in various metabolisms of plants, and are considered as one of the most important physiological parameters reflecting the overall metabolic level in plants (Doganlar et al. 2010). In this study, analysis of the protein content showed that the plantlets treated with the three nutrient solutions have significantly higher metabolic levels than that of the deionised water treatment (Table 2 ). The results of the physiological parameters showed that the caladium plantlets could grow well with normal physiological metabolism in the three nutrient solutions, which is a strong proof of the feasibility of the static hydroponic method for acclimatisation of in vitro caladium plantlets. Similar results have also been reported by Nhut et al. (2006) on S. tuberosum L. and Palee et al. (2012) on S. curtisii Hook. f.

Caladium is very sensitive to low temperature and chilling stress (Deng 2012). Due to the limitation of temperature conditions, its growth and ornamental period are usually short when cultivated in open fields in most of China. Therefore, hydroponic culture of in vitro or in vivo caladium plantlets indoors might extend its ornamental period. Several aspects of this technique still need to be investigated to optimise this hydroponic system. For example, ornamental value is an important evaluation factor for foliage plants, and therefore effects of nutrient solutions on foliar characteristics such as color of leaf main

TABLE 2. Variance of physiological parameters (mg/g FW) of the caladium plantlets after 30 days of acclimatization in the different nutrient solutions by using a static hydroponics system

\begin{tabular}{|c|c|c|c|c|c|c|}
\hline Treatments & $\begin{array}{l}\text { Chlorophyll } a \\
\text { content }\end{array}$ & $\begin{array}{c}\text { Chlorophyll } b \\
\text { content }\end{array}$ & $\begin{array}{c}\text { Total chlorophyll } \\
\text { content }\end{array}$ & $\begin{array}{c}\text { Carotenoid } \\
\text { content }\end{array}$ & $\begin{array}{l}\text { Soluble sugar } \\
\text { content }\end{array}$ & $\begin{array}{c}\text { Soluble protein } \\
\text { content }\end{array}$ \\
\hline Deionized water & $1.46 \pm 0.11 \mathrm{c}$ & $0.48 \pm 0.06 \mathrm{c}$ & $1.94 \pm 0.17 \mathrm{c}$ & $0.31 \pm 0.02 \mathrm{c}$ & $3.67 \pm 0.19 \mathrm{c}$ & $27.26 \pm 0.60 \mathrm{c}$ \\
\hline JG & $1.97 \pm 0.31 \mathrm{ab}$ & $0.64 \pm 0.12 \mathrm{ab}$ & $2.61 \pm 0.43 \mathrm{ab}$ & $0.38 \pm 0.08 b$ & $4.38 \pm 0.34 b$ & $32.93 \pm 1.71 \mathrm{~b}$ \\
\hline SCAU-B & $2.21 \pm 0.10 \mathrm{a}$ & $0.71 \pm 0.03 \mathrm{a}$ & $2.92 \pm 0.12 \mathrm{a}$ & $0.46 \pm 0.02 \mathrm{a}$ & $5.18 \pm 0.44 \mathrm{a}$ & $36.18 \pm 1.19 \mathrm{a}$ \\
\hline Hoagland & $1.82 \pm 0.13 b$ & $0.57 \pm 0.03 b$ & $2.40 \pm 0.17 b$ & $0.39 \pm 0.05 b$ & $4.11 \pm 0.49 b$ & $36.15 \pm 1.28 \mathrm{a}$ \\
\hline
\end{tabular}

Means \pm standard deviation within a column followed by the same letters are not significantly different according to Duncan's range test at $p<0.05$ JG: Japan Garden formula;

SCAU-B: South China Agriculture University formula B for leafy vegetables 
vein, blotches and margins need further study. Besides, minituber production by means of hydroponics has been realised in potato (Nhut et al. 2006; Ritter et al. 2001). Commercial production of caladium plants in the world is mostly forced from tubers. In this study, the plantlets did not form minitubers during the acclimatisation process, which may be due to the growth period which was too short to form minitubers. Establishment of an ideal hydroponic system for caladium tuber production using in vitro plantlets is needed in future study.

\section{CONCLUSION}

In summary, hydroponic culture has been proved to be an efficient way for acclimatisation of the in vitro grown caladium plantlets in this study. Water alone was not capable of maintaining healthy growth of the plantlets, and hydroponics using the three nutrient solutions could be a feasible method for acclimatisation of in vitro caladium plantlets in the static hydroponic culture system. Effects of different nutrient solutions on the ornamental value and minituber production of in vitro caladium plantlets during the acclimatisation process need further study.

\section{ACKNOWLEDGEMENTS}

This study was supported by the Scientific Research Project of Hubei Education Department (No. B2018024) and the College of Horticulture and Gardening of Yangtze University, China. We are especially grateful to Dr. Zhanao Deng (the University of Florida's Gulf Coast Research and Education Center, Wimauma, FL, USA.) for providing the 'Red Flash' caladium.

\section{REFERENCES}

Ahmed, E.U., Hayashi, T. \& Yazawa, S. 2004. Auxins increase the occurrence of leaf-color variants in caladium regenerated from leaf explants. Scientia Horticulturae 100: 153-159.

Asayesh,Z.M., Vahdati, K. \& Aliniaeifard, S. 2017. Investigation of physiological components involved in low water conservation capacity of in vitro walnut plants. Scientia Horticulturae 224: 1-7.

Bailey, S., Horton, P. \& Walters, R.G. 2004. Acclimation of Arabidopsis thaliana to the light environment: The relationship between photosynthetic function and chloroplast composition. Planta 218(5): 793-802.

Banijamali, S.M., Feizian, M., Bayat, H. \& Mirzaei, S. 2018. Effects of nitrogen forms and calcium amounts on growth and elemental concentration in Rosa hybrida cv. 'Vendentta'. Journal of Plant Nutrition 41(9): 1205-1213.

Bradford, M.M. 1976. A rapid and sensitive method for the quantitation of microgram quantities of protein utilizing the principle of protein-dye binding. Analytical Biochemistry 72(1-2): 248-254

Bradley, P. \& Marulanda, C. 2001. Simplified hydroponics to reduce global hunger. Acta Horticulturae 554: 289-295.

Cai, X.D. \& Deng, Z. 2016. Thidiazuron promotes callus induction and proliferation in Caladium $\times$ hortulanum Birdsey UF-4609. Propagation of Ornamental Plants 16(3): 90-97.
Cao, Z., Sui, S.Z., Cai, X.D., Yang, Q. \& Deng, Z. 2016. Somaclonal variation in 'Red Flash' caladium: Morphological, cytological and molecular characterization. Plant Cell, Tissue and Organ Culture 126: 269-279.

Cai, X.D., Cao, Z., Xu, S.X. \& Deng, Z. 2015. Induction, regeneration and characterization of tetraploids and variants in 'Tapestry' caladium. Plant Cell, Tissue and Organ Culture 120: 689-700.

Deng, Z. 2018. Caladium. In Ornamental Crops: Handbook of Plant Breeding, edited by Van Huylenbroeck, J. Volume 11. Springer: Cham. pp. 273-299.

Deng,Z. 2012.Caladium genetics and breeding: Recent advances. Floriculture and Ornamental Biotechnology 6: 53-61.

Doganlar, Z.B., Demir, K., Basak, H. \& Gul, I. 2010. Effects of salt stress on pigment and total soluble protein contents of three different tomato cultivars. African Journal of Agricultural Research 5(15): 2056-2065.

Hoagland, D.R. \& Arnon, D.I. 1950. The water-culture method for growing plants without soil. California Agricultural Experiment Station Circular 347: 1-32.

Hosseinzadeh, S., Verheust, Y., Bonarrigo, G. \& Hulle, S.V. 2017. Closed hydroponic systems: Operational parameters, root exudates occurrence and related water treatment. Reviews in Environmental Science and Bio/Technology 16(1): 59-79.

Kötting, O., Kossmann, J., Zeeman, S.C. \& Lloyd, J.R. 2010. Regulation of starch metabolism: The age of enlightenment? Current Opinion in Plant Biology 13(3): 320-328.

Kozai, T. 1991. Acclimation of micropropagated plantlets. In High-Tech and Micropropagation I. Biotechnology in Agriculture and Forestry, edited by Bajaj, Y.P.S. Berlin: Springer-Verlag. Volume 17. pp. 127-139.

Li, H.S. 2000. Experimental Principle and Technology of Plant Physiology and Biochemistry. Beijing: Higher Education Press (in Chinese).

Li, Q.G., Wang, J.X. \& Zhang, W.Y. 2010. Selection of hydroponics nutrient solution formulas for Caladium bicolor. Journal of Hebei Agricultural Sciences 14(9): 60-62.

Lichtenthaler, H.K. 1987. Chlorophylls and carotenoids: Pigments of photosynthetic biomembranes. Methods in Enzymology 148: 350-382.

Liu, S.Z. 2001. Nutrient solution. In Soilless Cultivation, edited by Guo, S.R. Beijing: China Agriculture Press. pp. 88-90.

Nhut, D.T., Nguyen, N.H. \& Thuy, D.T.T. 2006. A novel in vitro hydroponic culture system for potato (Solanum tuberosum L.) microtuber production. Scientia Horticulturae 110(3): 230-234.

Öztekin, G.B., Uludağ, T. \& Tüzel, Y. 2018. Growing spinach (Spinacia oleracea L.) in a floating system with different concentrations of nutrient solution. Applied Ecology and Environmental Research 16(3): 3333-3350.

Palee, J., Dheeranupattan, A.S., Jatisatienr, A., Wangkarn, S., Mungkornasawakul, P., Pyne, S., Ung, A. \& Sastraruji, T. 2012. Influence of plantlet age and different soilless culture on acclimatization of Stemona curtisii Hook. f. Asian Journal of Plant Sciences 11(6): 294-299.

Phantong, P., Machikowa, T., Saensouk, P. \& Muangsan, N. 2018. Comparing growth and physiological responses of Globba schomburgkii Hook. f. and Globba marantina L. under hydroponic and soil conditions. Emirates Journal of Food and Agriculture 30(2): 157-164.

Phonpho, S. \& Saetiew, K. 2017. Selection of appropriate species of plants for indoor vertical garden. International Journal of Agricultural Technology 13(1): 119-129. 
Pospóšilová, J.,Tichá, I., Kadleček, P., Haisel,D. \& Plzáková,Š . 1999. Acclimatization of micropropagated plants to ex vitro conditions. Biologia Plantarum 42(4): 481-497.

Ritter, E., Angulo, B., Riga, P., Herran, C., Relloso, J. \& San, J.M. 2001. Comparison of hydroponic and aeroponic cultivation systems for the production of potato minitubers. Potato Research 44(2): 127-135.

Sutthinon, P., Pan-aon, K., Meesawat, U. \& Jantasilp, A. 2015. Acclimatization of in vitro germinated seedlings of tiger orchid (Grammatophyllum speciosum Blume.) in hydroponic culture using dynamic root floating technique (DRFT) with chitosan spraying. Thai Journal of Agricultural Science 48(2): 47-53

Thongpukdee,A., Thepsithar, C. \& Chiensil, P. 2010. Somaclonal variation of Caladium bicolor (Ait.) Vent. 'Jao Ying' after in vitro culture propagation. Acta Horticulturae 855: 281-288.

Trejo-Téllez, L. \& Gómez-Merino, F.C. 2012. Nutrient solutions for hydroponic systems. In Hydroponics-A Standard Methodology for Plant Biological Researches, edited by Asao, T. London: InTech. pp. 1-22.
Xu, Q.L. \& Cui, L.H. 2014. Comparison on purifying effect of the domestic sewage by several wetland plants. Journal of Anhui Agricultural Sciences 42(1): 204-206.

College of Horticulture and Gardening

Yangtze University

Jingzhou, Hubei 434025

China

*Corresponding author; email: caixiao.dong@163.com

Received: 5 December 2018

Accepted: 18 May 2019 